Original paper

\title{
Biological effects induced by doses of mammographic screening
}

\author{
Leslie Pereira $^{\mathrm{a}, \mathrm{b},{ }^{*},}$, Marcella T. Ferreira ${ }^{\mathrm{c}}$, Antonio Gilcler F. Lima ${ }^{\mathrm{c}}$, Camila Salata ${ }^{\mathrm{d}}$, \\ Samara C. Ferreira-Machado ${ }^{\mathrm{e}, \mathrm{f}}$, I. Lima ${ }^{\mathrm{b}}$, Verônica Morandi ${ }^{\mathrm{c}}$, Luís A.G. Magalhães ${ }^{\mathrm{e}}$ \\ ${ }^{a}$ Department of Medical Physics, Institute of Radiation Protection and Dosimetry (IRD), Av. Salvador Allende, 3773, Barra da Tijuca, Rio de Janeiro, RJ CEP 22783- \\ 127, Brazil \\ ${ }^{\mathrm{b}}$ Nuclear Engineering Department (DNC), Federal University of Rio de Janeiro (UFRJ), sala 206, Centro de Tecnologia, Av. Horácio Macedo, 2030, Bloco G, Fundão, \\ Rio de Janeiro, RJ CEP 21941-941, Brazil \\ ${ }^{\mathrm{c}}$ Department of Cell Biology, University of the State of Rio de Janeiro (UERJ), Pavilhão Haroldo Lisboa da Cunha, LabAngio, Rua São Francisco Xavier, 524, Maracanã, \\ Rio de Janeiro, RJ CEP 20550-900, Brazil \\ d CGMI/DRS, Brazilian National Nuclear Energy Comission (CNEN), Rua General Severiano, 90, Botafogo, Rio de Janeiro, RJ CEP 22290-901, Brazil

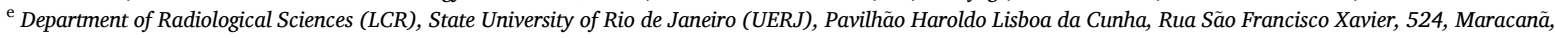 \\ Rio de Janeiro, RJ CEP 20550-900, Brazil \\ ${ }^{\mathrm{f}}$ Department of General Biology, Federal Fluminense University, Niterói, RJ CEP 21045-900, Brazil
}

\section{A R T I C L E I N F O}

\section{Keywords:}

Breast cell

Mammography

Apoptosis

$\gamma \mathrm{H} 2 \mathrm{AX}$

\begin{abstract}
A B S T R A C T
Purpose: Mammography is the diagnostic imaging practice used in screening to detect early lesions suspected of malignancy. It uses a low energy X-ray beam in which a low dose in the order of 2-3 mGy is delivered to patient breast cells. However, it has been speculated that it could lead to significant cell damage, when compared to conventional X-ray. We investigated the biological effects of low doses, with mean glandular doses (MGDs) of $2.5 \mathrm{mGy}$ and $2.5+2.5 \mathrm{mGy}$, on mammary cells in vitro.

Methods: We used the non-tumorigenic cell line (MCF-10A) and two tumor cells lines (MCF-7 and MDA-MB-231). Colony formation, apoptosis, and double-strand DNA breaks (DSBs) were quantified.

Results: The selected MGD regimens did not alter the formation of colonies by any of the cell lines. MCF-7 cells exhibited a markedly increase in apoptosis, $24 \mathrm{~h}$ after the single-dose protocol; MCF-10A cells underwent apoptosis only after $72 \mathrm{~h}$, with both irradiation regimens, while MDA-MB-231 cells (highly invasive and metastatic) were not susceptible to apoptosis. The detection of $\gamma \mathrm{H} 2 \mathrm{AX}$ histone in the nuclei of irradiated cells showed that the double-dose resulted in increase of DSBs, especially in tumor cell lines.

Conclusions: Although the health benefits of early breast screening remain indisputable, our future perspective is to better understand the biological basis for the effects of low dose radiation on breast cells and to investigate if and under what conditions there would be a risky situation in repeated mammography screening, in both asymptomatic and symptomatic women.
\end{abstract}

\section{Introduction}

Mammography is the diagnostic imaging practice of choice used in breast screening to detect early lesions suspected of malignancy. The radiation beam used in this practice is classified as low energy, i.e., low doses of ionizing radiation (IR). However, it has been speculated whether X-rays with mammographic quality could be biologically effective in causing cell damage [1-3]. In fact, considerable awareness has been raised regarding breast screening, in the sense that it must significantly overcome the possible risk of radio-induced cancer [4-8].
Mammographic screening aims to detect breast cancer at an early stage which, if treated immediately, can reduce the mortality rate by $15 \%$ to $30 \%[9,10]$. Two images are routinely taken within a few minutes interval. Additionally, several parameters can increase the mean glandular dose (MGD), such as density and volume of the breast tissue, lack of breast compression [11,12], physical parameters, and the design of the mammography $[9,13]$. Furthermore, individual radiosensitivity (age, cell type, fractional dose, radiation quality, and oxidative stress) can also be a parameter of response to radiation, although this is difficult to diagnose and quantify $[8,14-16]$.

\footnotetext{
* Corresponding author at: Department of Medical Physics, Institute of Radiation Protection and Dosimetry (IRD), Av. Salvador Allende, 3773, Barra da Tijuca, Rio de Janeiro, RJ CEP 22783-127, Brazil.

E-mail addresses: leslie@ird.gov.br (L. Pereira), camila.salata@cnen.gov.br (C. Salata), inaya@con.ufrj.br (I. Lima), veronica@uerj.br (V. Morandi).
} 
The International Commission for Radiological Protection (ICRP) attributes the same risk relative to X-rays of all energies. At low doses of radiation $(<100 \mathrm{mGy})$, specific mechanisms were observed in cellular models, the so-called hyper-radiosensitivity at low doses [17]. Therefore, a better evaluation of the risks of exposure to low dose radiation is necessary to understand the biological mechanisms of radio-induced carcinogenesis. Moreover, the ICRP, in 2007 [4], increased the breast tissue weighting factor from 0.05 to 0.12 , thus considering the breast as a tissue more sensitive to radiation.

The biological impact of the larger linear energy transfer (LET) from low-energy mammography X-rays compared to high-energy photons is still controversial. The ICRP suggests that there are significant differences in the relative biological efficacy (RBE) of different qualities of low LET radiation, but still recommends the use of an RBE of 1 for $30 \mathrm{kV}$ $\mathrm{X}$-rays [5]. In the intermediate energy range of $20 \mathrm{keV}$ to $100 \mathrm{keV}$, relevant for medical diagnostics, a change from the photoelectric effect to the Compton effect causes a transient decrease in electron energies. In this range, electron energy increases with increasing photon energy, which implies that high-energy photons need less dense ionizing radiation and are therefore less effective per unit dose. The ionization density is similar for X-rays of $30 \mathrm{kVp}$ (mammography) and X-rays of $200 \mathrm{kVp}$, according to dose distributions in advanced LET a higher RBE for mammography of $30 \mathrm{kVp}$ compared to X-rays of $200 \mathrm{kVp}$, suggesting, that mammography X-rays cause an increased risk of breast cancer. The Auger electron that accompanies most photoelectrons, but only a minority of Compton electrons, may slightly increase the effectiveness of mammography X-rays, but the low dose RBE of mammography X-rays should be 1 .

IR can induce DNA double-strand breaks (DSBs), an injury considered critical, as they can cause chromosomal instability leading to cellular changes that favor carcinogenesis or cell death [18]. The formation, in the nucleus, of $\gamma \mathrm{H} 2 \mathrm{AX}$ foci - a phosphorylated form of $\mathrm{H} 2 \mathrm{AX}$ histone - has been quantitatively correlated with the occurrence of DSBs and it is considered a potential and reliable biomarker for the effects of low dose IR exposure [19]. So far, several studies [20-22] have contributed to a better understanding of the responses to low dose exposure. However, most of them did not follow the protocols for mammographic procedures, i.e. doses in the order of 2-3 mGy, lowenergy X-rays, and repeated exposures or with adequate cellular model, non-tumoral and untransformed breast epithelial cells (Table 1).

The development of human cancers through the transformation of normal cells into neoplastic cells is a complex event that develops in multiple stages [23]. Regarding radio-induced carcinogenesis, the effects of hypersensitivity, adaptive response, bystander response, hormesis, and sensitivity threshold at low doses are key factors to be considered $[1,2]$. The neoplastic transformation undergone by healthy cells includes uncontrolled proliferation and genomic instability [24]. Breast tissues are highly sensitive to the effects of IR, making the risks of radio-induced cancer in mammographic screening a concern $[25,26]$. Aged epithelial cells have less capacity to deal with DNA damage [27], and repeated dose of mammography was shown to be more harmful for high-risk breast cancer patients, so a single image should be taken in breast screening [28]. On the other hand, it was shown that nonsignificant changes were detectable in nontumorigenic breast cells exposed to a single mammogram [29], and that cells irradiated with a low level radiation dose might be able to efficiently repair DNA damage [30].

In this respect, the present study aimed to evaluate whether biological effects of low dose radiation could be induced in tumoral and non-tumorigenic breast cells in vitro, when using irradiation regimens compatible to those applied to an average breast composition of $50 \%$ fibroglandular and 50\% adipose tissues, in the practice of mammographic screening. Following the recommendation of international protocols [31], a MGD of $2.5 \mathrm{mGy}$ was chosen. The techniques used to

Table 1

Radiobiological studies that evaluated the effects of mammographic irradiations. In the practice of mammographic screening a breast with an average composition of $50 \%$ fibroglandular and 50\% adipose tissues, requires $28 \mathrm{kV}$ X-rays, anode/filter Mo/Mo combination, and $63 \mathrm{mAs}$. The result is an MGD of $2.5 \mathrm{mGy}$, per view.

\begin{tabular}{|c|c|c|c|c|c|}
\hline References & Cellular model & Dose (mGy) & $* \mathrm{~A} / \mathrm{F}$ & $\begin{array}{l}\text { Voltage } \\
\text { (X-rays) }\end{array}$ & Conclusions \\
\hline Ko et al. (2004) & $\begin{array}{l}\text { HeLa } \times \text { skin fibroblast hybrid CGL1 cell } \\
\text { line }\end{array}$ & $0.5-220$ & - & $28 \mathrm{kVp}$ & $\begin{array}{l}\text { Neoplastic transformation. Higher transformation rate at doses }>11 \mathrm{mGy} \\
\text { and lower at doses }<11 \mathrm{mGy} \text {. }\end{array}$ \\
\hline $\begin{array}{l}\text { Lehnert et al. } \\
\qquad(2006)\end{array}$ & Human immortalised MCF-12A cell line & $500-10,000$ & $\mathrm{~W} / \mathrm{Al}$ & $25 \mathrm{kV}$ & $\begin{array}{l}\text { Micronuclei and clonogenic cell survival. }{ }^{* *} \mathrm{RBE} \text { of } 25 \mathrm{kV} \text { X-rays higher } \\
\text { than } 1 \text { with cell survival data. }\end{array}$ \\
\hline $\begin{array}{l}\text { Lehnert et al. } \\
\qquad(2008)\end{array}$ & Human immortalised MCF-12A cell line & $500-10,000$ & $\begin{array}{l}\mathrm{W} / \\
\mathrm{Cu}\end{array}$ & $10 \mathrm{kV}$ & $\begin{array}{l}\text { Micronuclei and clonogenic cell survival. }{ }^{* *} \mathrm{RBE} \text { increases when X-ray } \\
\text { energy decrease. }\end{array}$ \\
\hline $\begin{array}{l}\text { Beyreuther } \\
\text { et al. (2009) }\end{array}$ & $\begin{array}{l}\text { Human immortalised epithelial 184A1 } \\
\text { and MCF-12A cell lines }\end{array}$ & $500-6000$ & $\begin{array}{l}\text { W/Al } \\
\mathrm{W} / \\
\mathrm{Cu}\end{array}$ & $\begin{array}{l}10 \mathrm{kV} \\
25 \mathrm{kV}\end{array}$ & $\begin{array}{l}\text { Chromosome breaks and aberrations. }{ }^{* *} \mathrm{RBE} \text { increases when X-ray energy } \\
\text { decrease. }\end{array}$ \\
\hline $\begin{array}{l}\text { Beyreuther } \\
\text { et al. (2009) }\end{array}$ & $\begin{array}{l}\text { Human immortalised epithelial 184A1 } \\
\text { and MCF-12A cell lines }\end{array}$ & $500-6000$ & $\begin{array}{l}\text { W/Al } \\
\mathrm{W} / \\
\mathrm{Cu}\end{array}$ & $\begin{array}{l}10 \mathrm{kV} \\
25 \mathrm{kV}\end{array}$ & $\begin{array}{l}\text { Co-localisation of } \mathrm{H} 2 \mathrm{AX} \text { and 53BP1. RBE increases when X-ray energy } \\
\text { decrease. }\end{array}$ \\
\hline $\begin{array}{l}\text { Colin et al. } \\
\text { (2013) }\end{array}$ & 30 human primary epithelial cells & $\begin{array}{l}{ }_{2}^{*} 2,4 \text { and } 2+ \\
\end{array}$ & $\begin{array}{l}\text { Mo/ } \\
\text { Mo }\end{array}$ & $28 \mathrm{kVp}$ & $\begin{array}{l}\gamma \mathrm{H} 2 \mathrm{AX} \text { foci. } 28 \mathrm{kV} \mathrm{X} \text {-rays Mammography induce DSB that may be severe in } \\
\text { HR patient. }\end{array}$ \\
\hline $\begin{array}{l}\text { Mills et al. } \\
\text { (2015) }\end{array}$ & Human immortalised MCF-10A cell line & $0-30$ & $\begin{array}{l}\mathrm{Rh} / \\
\mathrm{Rh}\end{array}$ & $29 \mathrm{kV}$ & $\begin{array}{l}\text { No significant changes in the number of 53BP1 foci were detected in cells } \\
\text { exposed to a single mammogram, however, exposures to doses equivalent } \\
\text { to three or ten mammograms yielded significant increases in 53BP1 foci. }\end{array}$ \\
\hline $\begin{array}{l}\text { Depuydt et al. } \\
\text { (2018) }\end{array}$ & $\begin{array}{l}\text { Non-cancerous, freshly resected breast } \\
\text { tissue, collected during surgery }\end{array}$ & $0-500$ & $\begin{array}{l}\text { Mo/ } \\
\text { Mo }\end{array}$ & $30 \mathrm{kVp}$ & $\begin{array}{l}\text { Existence of a low dose ( } 0-20 \mathrm{mGy} \text { ) hypersensitive response. The DSB } \\
\text { induced by mammography is more difficult to repair and the } \\
\text { mammography induced DSB resulted in a higher number of chromosomal } \\
\text { aberrations. }\end{array}$ \\
\hline This work & $\begin{array}{l}\text { Human immortalised MCF-10A cell } \\
\text { line, and tumor cells lines MCF-7 and } \\
\text { MDA-MB-231 }\end{array}$ & $\begin{array}{l}{ }^{\#} 2.5 \text { and } 2.5 \\
+2.5\end{array}$ & $\begin{array}{l}\text { Mo/ } \\
\text { Mo }\end{array}$ & $28 \mathrm{kV}$ & $\begin{array}{l}\text { The MGD did not alter the formation of colonies by any of the cell lines. } \\
\text { MCF- } 7 \text { cells exhibited a markedly increase in apoptosis, } 24 \text { h after the } \\
\text { single-dose protocol. The detection of } \gamma \mathrm{H} 2 \mathrm{AX} \text { histone in the irradiated cells } \\
\text { showed that the double-dose resulted in an increase of DSBs, especially in } \\
\text { tumor cell lines. }\end{array}$ \\
\hline
\end{tabular}

\footnotetext{
* A/F = Anode/Filter; Mo/Mo = Molibidenium/Molibidenium; Rh/Rh = Rhodium/Rhodium; W/Al = Tungsten/Aluminum; W/Cu = Tungsten/Copper.

** $\mathrm{RBE}=$ Relative Biological Effectiveness.

\# MGD $=$ Mean Glandular Doses.
} 
monitor and compare cell responses after exposure to X-ray beams were the clonogenic (proliferation) assay, apoptosis quantification by flow cytometry, and $\gamma \mathrm{H} 2 \mathrm{AX}$-positive immunostaining in three types of human breast cells: (a) a non-tumorigenic cell line (MCF-10A), derived from a benign fibrocystic breast biopsy; (b) a breast cancer cell line exhibiting an intermediate stage of neoplastic transformation, with a less aggressive profile and low metastatic potential, an estrogen receptor-positive adenocarcinoma (MCF-7) and; (c) a highly invasive and metastatic, triple-negative adenocarcinoma tumor cell line (MDA-MB-231).

\section{Material and methods}

\section{Cell culture}

The three human breast epithelial cell lines MCF-10A, MCF-7, MDAMB-231 were acquired from the American Type Culture Collection (ATCC) (Manassas, VA, USA). The MCF-10A cell line was cultured in high glucose DMEM (GIBCO) supplemented with $10 \%$ fetal horse serum (FHS, Sigma-Aldrich) and the following additives: $10 \mu \mathrm{g} / \mathrm{mL}$ insulin (Sigma-Aldrich), $0.5 \mu \mathrm{g} / \mathrm{mL}$ hydrocortisone (Sigma-Aldrich), $20 \mu \mathrm{g} / \mathrm{mL}$ epidermal growth factor (EGF, Sigma-Aldrich), and $1 \%$ penicillin-streptomycin (Sigma-Aldrich). The MCF-7 and MDA-MB-231 cell lines were cultured in RPMI medium (GIBCO) supplemented with $10 \%$ fetal bovine serum (FBS, GIBCO) and 1\% penicillin-streptomycin (Sigma-Aldrich). The cells were kept in an incubator at $37{ }^{\circ} \mathrm{C}$ and $5 \%$ $\mathrm{CO}_{2}$. All cell lines were identified by genotypic authentication through the analysis of their STR profiles (Short Tandem Repeats) in the DNA Diagnostic Laboratory (LDD/UERJ, Rio de Janeiro, Brazil).

\section{Mammographic irradiations}

The cell lines were irradiated with a clinical mammograph SIEMENS/Mammomat 1000 at the Institute for Radioprotection and Dosimetry in Rio de Janeiro, Brazil. To obtain the MGD of $2.5 \mathrm{mGy}$, the setup parameters were as follows: anode/filter Mo/Mo combination, 28 $\mathrm{kV}(\mathrm{E} \approx 16.2 \mathrm{keV}), 63 \mathrm{mAs}$, and dose rate of $0.138 \mathrm{mGy} / \mathrm{min}$. A compression tray was used, and the irradiations were carried out at room temperature. The kerma at the input surface and dose rate of the Xray beam was measured using a solid-state detector (Nomex, PTW). For cell irradiation, in the clonogenic and apoptosis assays, the culture flask $\left(25 \mathrm{~cm}^{2}\right)$ was placed inside a $4.5 \mathrm{~cm}$ thick polymethyl methacrylate (PMMA) breast phantom. For the immunostaining assay (nuclear $\gamma \mathrm{H} 2 \mathrm{AX}$ detection), cells were irradiated in a 24-well culture plate placed between two $1 \mathrm{~cm}$ acrylic plates, at approximately $4.5 \mathrm{~cm}$ thick.

The protocols [29] established were: (1) non-irradiated control; (2) single-dose MGD of $2.5 \mathrm{mGy}$; and (3) repeated MGD of $2.5+2.5 \mathrm{mGy}$ (equivalent to two mammographic images separated by a one-minute interval).

\section{Clonogenic assay}

The cells $\left(3 \times 10^{4}\right.$ cells/flask) were irradiated in culture flasks (25 $\mathrm{cm}^{2}$ ) filled with phosphate-buffered saline (PBS, 1:10) and placed inside a PMMA phantom. After irradiation, PBS was removed, and the cells were detached from the flask through the enzymatic action of $0.025 \%$ trypsin (diluted in culture medium). Cells were then counted and seeded $\left(2 \times 10^{2}\right.$ cells/well) in 6-well plates, in their respective culture media. After 14 days at $37{ }^{\circ} \mathrm{C}$ and $5 \% \mathrm{CO}_{2}$, the cells were fixed with $3.7 \%$ formaldehyde in PBS (1:10) and stained with $0.5 \%$ violet crystal. Colonies were counted in each well on an inverted microscope (Zeiss Axiovert) and only colonies with more than 50 cells were considered. The number of colonies formed in the respective control condition (nonirradiated cultures) was used in the calculation of the plating efficiency, that was then used to calculate the survival fraction of the irradiated samples [32].

\section{Flow cytometry assay}

MCF-10A, MCF-7, and MDA-MB-231 cells were grown in culture flasks $\left(25 \mathrm{~cm}^{2}\right)$. Before irradiation, the medium was removed, and the flasks were filled with PBS and placed inside a PMMA phantom. After irradiation, the apoptotic response in the cell lines was measured at 0 , 24,48 , and $72 \mathrm{~h}$ by flow cytometry on a BD Accuri C6 flow cytometer (5 $\times 10^{3}$ events), using the Annexin V Apoptosis Detection Kit (BD Biosciences) [33]. The percentage of apoptosis was estimated from the number of cells positive for Annexin V-FITC and negative for propidium iodide (PI).

\section{Detection of $\gamma H 2 A X$ foci by immunofluorescence}

Cells were seeded $\left(3 \times 10^{4}\right.$ cells/well) in the wells of a 24-well plate containing round coverslips ( $\varnothing 13 \mathrm{~mm}$ ) and subsequently irradiated. At four different times $(0,15,30$, and $60 \mathrm{~min})$ after irradiation, the cells were fixed with absolute methanol for $5 \mathrm{~min}$ at room temperature. Cultures were then blocked with $1 \%$ bovine serum albumin (BSA) in PBS overnight and incubated with anti- $\gamma \mathrm{H} 2 \mathrm{AX}{ }^{\mathrm{ser} 139}$ antibody (1:200, MerckMillipore) in $50 \mathrm{mM}$ Tris buffer containing $0.9 \% \mathrm{NaCl}$ and $1 \%$ BSA (TBS/ BSA) for $40 \mathrm{~min}$. Three washes were performed with PBS. Cells were subsequently incubated with Alexa Fluor 555 goat anti-rabbit IgG $(\mathrm{H}+$ L) antibody (1:400, A-21428 Invitrogen) in TBS/BSA with 10\% goat serum (G9023 Sigma) for $40 \mathrm{~min}$. Coverslips were mounted on slides with ProLong Gold Antifade containing DAPI (P36935 Invitrogen). All slides were analyzed using the Evos-fl microscope, model M5000 (Thermo Scientific), equipped with fluorescence and triple-pass filter band. Two types of analyses were performed. In the first one, the number of $\gamma \mathrm{H} 2 \mathrm{AX}$ foci (immunofluorescence labeling) in 1000 cells was determined. The $\gamma \mathrm{H} 2 \mathrm{AX}$ label was quantified using the image processing software Image J. In the second analysis, at 100x magnifications, 100 nuclei of the cultured epithelial cells bearing $\gamma \mathrm{H} 2 \mathrm{AX}$ foci were used for each experiment and the number of foci per cell was counted. A repair time of 15 min was chosen to count ionizing radiation-induced DSBs. Based on the number of observed $\gamma \mathrm{H} 2 \mathrm{AX}$ foci in individual nuclei, a classification criterion was designed, in order to produce a score system: nucleus with less than 5 foci $(x<5)$, nucleus with foci between 5 and 15 ( $5<\mathrm{x}<15)$, and nucleus with more than 15 foci $(x>15)$.

\section{Statistical analysis}

Expressed were data as mean \pm standard deviation (SD) from at least three independent experiments. The difference between the experimental groups was assessed by the ANOVA test (analysis of variance), followed by Bartlett's post-test, through the GraphPad Prism 5.01 program (Intuitive Software for Science).

\section{Results}

\section{Clonogenic assay}

Increased proliferation is known to be a remarkable behaviour of cancer cells [24]. We assessed the breast cell lines 14 days after irradiation for ther ability to generate clonal colonies at low density seeding $\left(20\right.$ cells $/ \mathrm{cm}^{2}$ ). The results did not show any significant difference among the conditions tested (Fig. 1). Since proliferative responses to low dose irradiation might be descrete (as opposed to the drastic effects normally observed with high dose irradiation protocols), we considered the possibility that any small variations in cell growth could be masked in this assay.

\section{Analysis of cell apoptosis by flow cytometry}

The rate of apoptotic cells by flow cytometry at 24,48 , and $72 \mathrm{~h}$ after irradiation was determined. As shown in Fig. 2, significant increases in 
MCF-10A

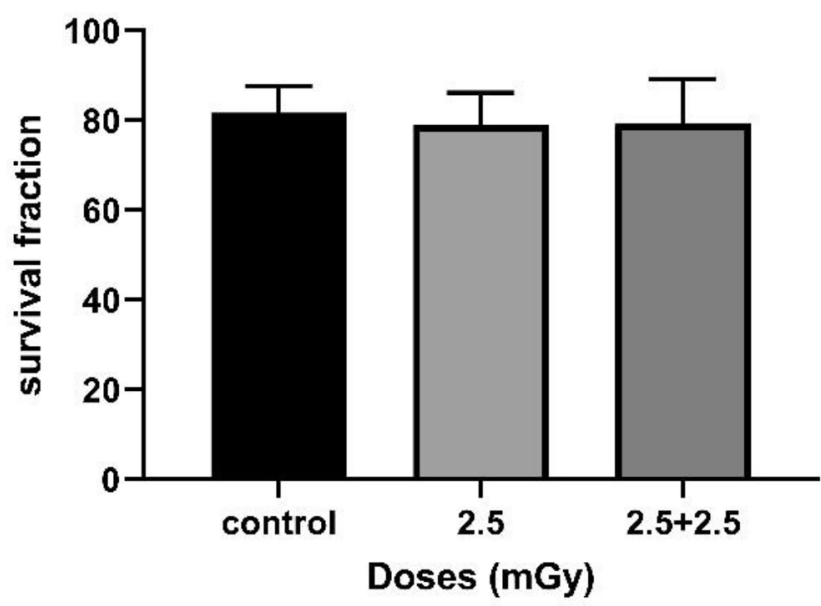

MCF7

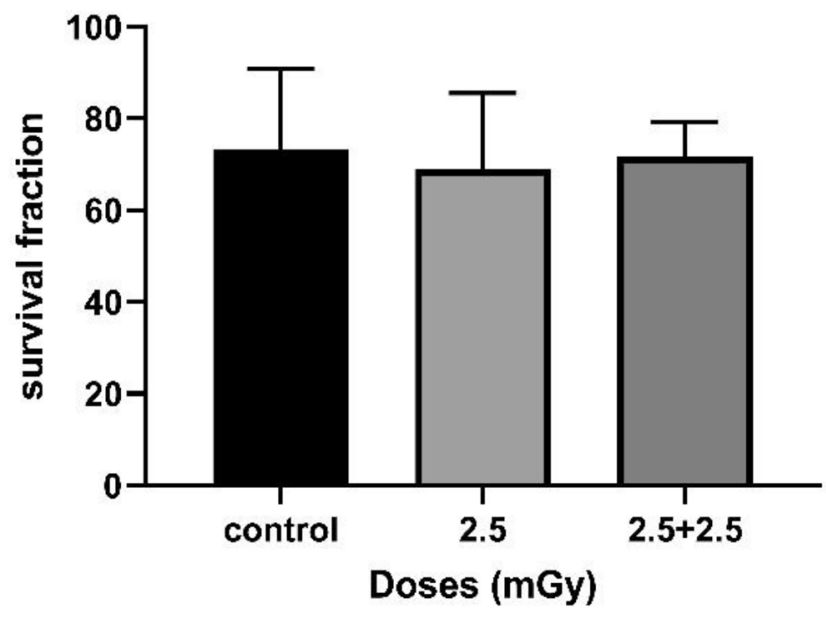

MDA-MB-231

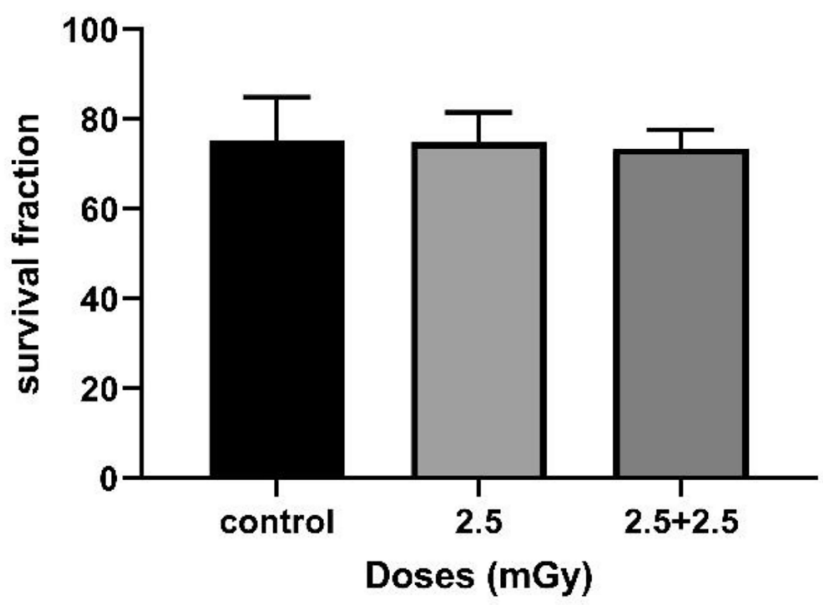

Fig. 1. Clonogenic cell proliferation in breast cell lines irradiated with MGDs of $2.5 \mathrm{mGy}$ and $2.5+2.5 \mathrm{mGy}$. (a) MCF-10A. (b) MCF-7. (c) MDA-MB-231. The results represent the mean $\pm \mathrm{SD}$ of at least three experiments.
MCF-10A

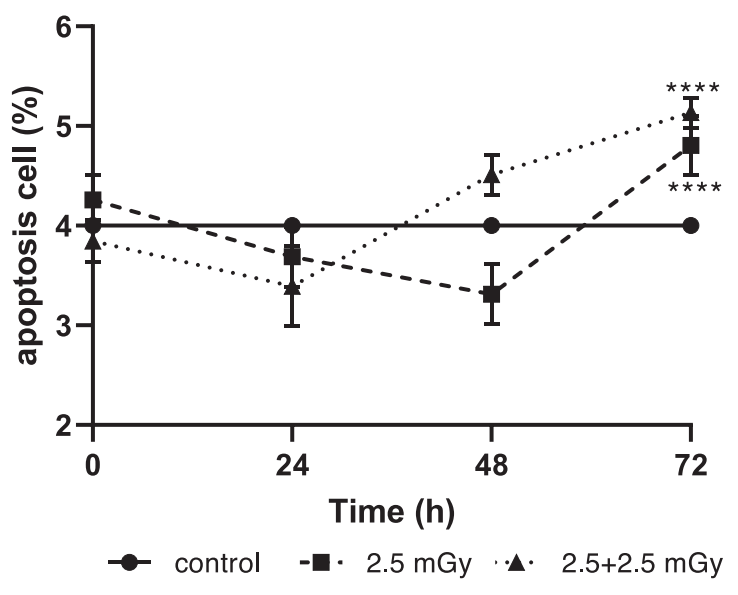

MCF-7

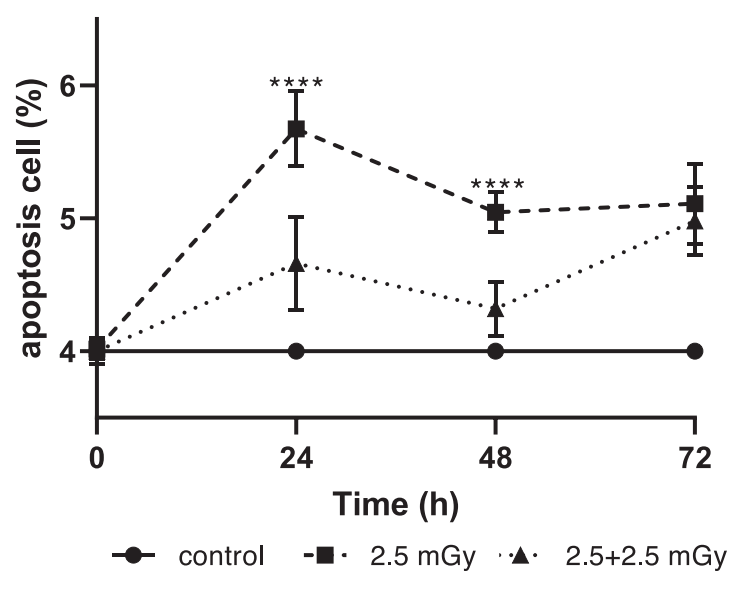

MDA-MB-231

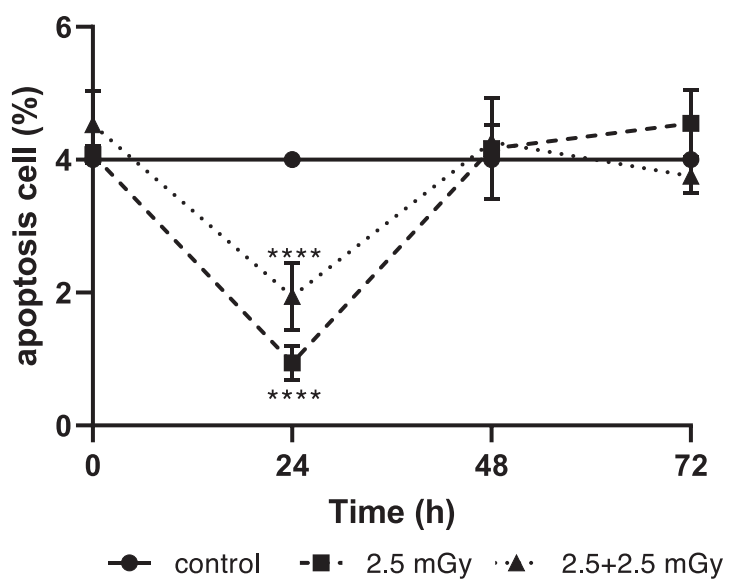

Fig. 2. Apoptosis in breast cells after irradiation with MGDs of $2.5 \mathrm{mGy}$ and $2.5+2.5 \mathrm{mGy}$. The results represent the mean \pm SD of at least three experiments and have the significance of $\mathrm{P}<0.0001(* * * *), \mathrm{P}<0.01(* *)$, and $\mathrm{P}<$ $0.05(*)$, as comparedto the respective non-irradiated control. 
apoptosis were observed in MCF10A cells with both irradiation regimens (MGDs of $2.5 \mathrm{mGy}$ and $2.5+2.5 \mathrm{mGy}$ ), but only after $72 \mathrm{~h}$ postirradiation. The apoptotic rates for MCF-7 cells (non-invasive breast tumor cells) exhibited a markedly different behavior from the other two cell lines, with a significant increase in $24 \mathrm{~h}$, mainly for those cells that received a single MGD (apoptotic rates of approximately 40\%). MDAMB-231 cell line were barely affected by any of the irradiation protocols, regarding apoptosis susceptibility.

\section{Detection of $\gamma H 2 A X$ foci by immunofluorescence}

The occurrence of DSBs was investigated by detecting the activation of histone H2AX, a reliable and sensitive molecular indicator of DNA damage. The phosphorylated form $\gamma \mathrm{H} 2 \mathrm{AX}$ was detectable in both nonirradiated and irradiated cells. The positive staining for $\gamma \mathrm{H} 2 \mathrm{AX}$ is indicated by white arrows, on Fig. 3 a.

The time-course quantification of cells exhibiting $\gamma \mathrm{H} 2 \mathrm{AX}$ foci is shown in Fig. 3b. By examining 1000 cells per time-point, a significant increase in the number of cells positively stained for activated histone was observed in the cancer cell lines, MCF-7 and MDA-MB-231, especially for those cells submitted to a double exposure (MGD of $2.5+2.5$ mGy). To a lesser extent, a smaller but significant increase in $\gamma \mathrm{H} 2 \mathrm{AX}$ staining, which was constant over time, was also detected in the nontumorigenic MCF-10A cell line, under the same repeated irradiation regimen.

We also quantified the number of $\gamma \mathrm{H} 2 \mathrm{AX}$ foci per cell, after $15 \mathrm{~min}$ of irradiation, as shown in Fig. 3c. Our results showed that the largest number of cells was found in the foci group $5<\mathrm{x}<15$, for the nontumorigenic cell line MCF-10A (75-82\%), while the smallest number of cells was found in the $x>15$ group (4-5\%). Concerning the MDA-MB231 cell line, the largest number of cells was classified within $\mathrm{x}>15$ group, regardless of the irradiation exposure. We also found that, for MCF-7 cells, the $2.5+2.5 \mathrm{mGy}$ irradiation exposure almost doubled the amount of cells in the the $x>15$ group, while the single-dose of $2.5 \mathrm{mGy}$ only slightly changed the distribution of $\gamma \mathrm{H} 2 \mathrm{AX}$ foci among the three score groups.

\section{Discussion}

The MCF10A human mammary epithelial cell line, previously derived from a biopsy of a benign fibrocystic disease [36], is a widely used model for studying non-tumorigenic breast cell behaviour. This spontaneously immortalized cell line has preserved some of the main features of differentiated breast epithelium, including lack of anchorageindependent growth and dependence on growth factors and hormones for proliferation and survival [36]. For these morphofunctional characteristics, these cells were considered suitable for the present investigation.

We first thought to evaluate the proliferative profile of the irradiated breast cells through a classic clonogenic assay. This method allows researchers to study cell survival and proliferation after treatments with radiation or other toxic agents. Although this assay is the most widely used to assess radiation-induced cell survival [32], the results obtained in the present work did not allow any distinctions regarding the proliferative capacity of the cells after exposure to ionizing radiation, in doses equivalent to those provided by regular mammography screenings. So, we decided to use other methods, in order to more accurately address the cellular responses to the two irradiation protocols under investigation here.

Flow cytometric analysis showed that the non-tumorigenic cell line MCF-10A exibited an increased apoptosis index, reaching a maximum value at $72 \mathrm{~h}$, for both irradiation regimens $(2.5 \mathrm{mGy}$ and $2.5+2.5$ mGy). This result strongly suggested that MGD induced damage to DNA molecules, which probably could not be corrected by the DNA repair machinery. For the MCF-7 tumor cell line, which is less aggressive and has a low metastatic potential, apoptosis was always higher than the index observed for the MDA-MB-231 cell line, reaching its highest value at $24 \mathrm{~h}$. In fact, no significant apoptosis was observed in MDA-MB-231
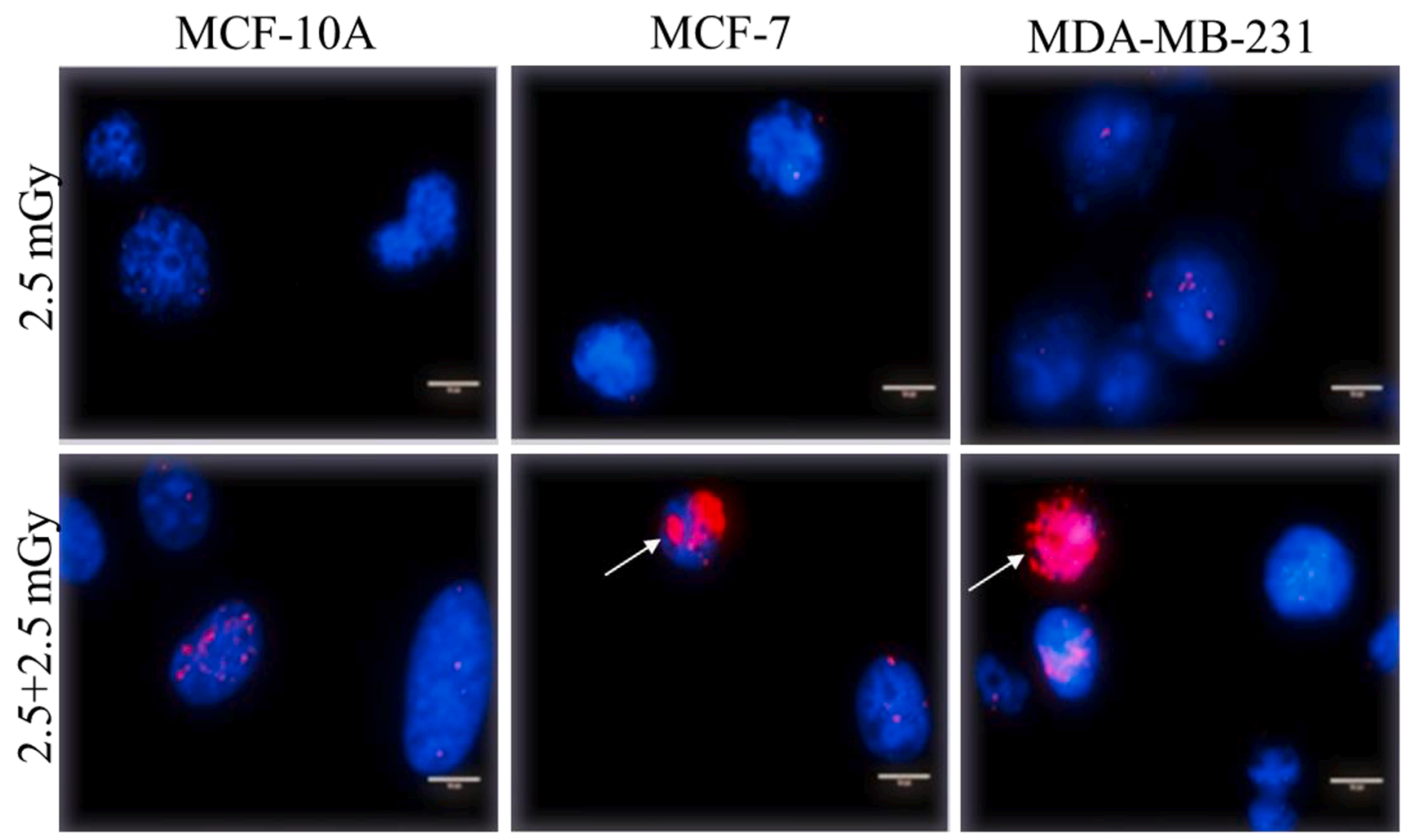

Fig. 3. (a). $\gamma \mathrm{H} 2 \mathrm{AX}$ foci of different sizes and intensities, induced by MGDs of 2.5 and $2.5+2.5 \mathrm{mGy}$ in three different breast cell lines, after15 min of irradiation; calibration bars $=100 \mu \mathrm{m}$, (b). Temporal analysis on the activation of histone $\gamma \mathrm{H} 2 \mathrm{AX}$ in breast cells irradiated with MGDs of $2.5 \mathrm{mGy}$ and $2.5+2.5 \mathrm{mGy}$. The results represent the mean \pm SD of at least three experiments, with significance of $\mathrm{P}<0.0001$ ( $* * * *)$, as compared to the respective non-irradiated control, (c). Analysis of the number of $\gamma \mathrm{H} 2 \mathrm{AX}$ foci per cell after $15 \mathrm{~min}$ irradiation with MGDs of $2.5 \mathrm{mGy}$ and $2.5+2.5 \mathrm{mGy}$ ( $\mathrm{x}=$ foci). 


\section{MCF-10A}

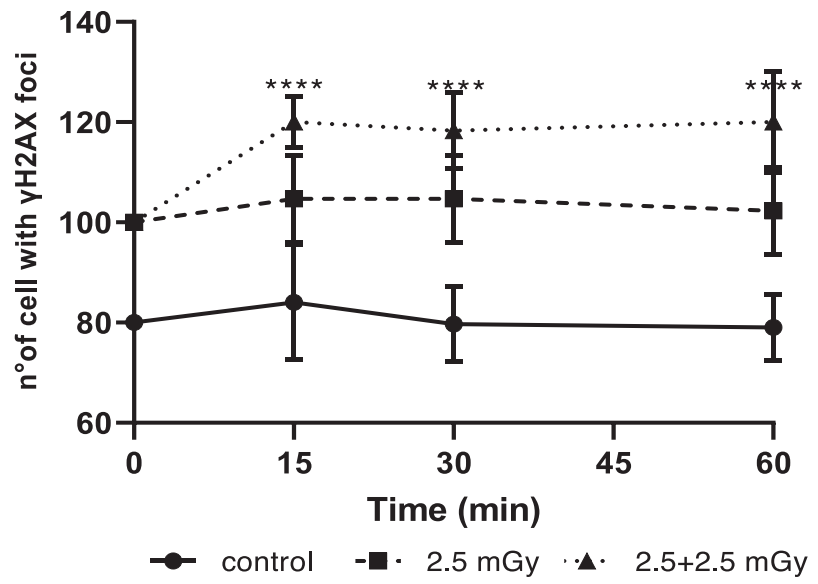

MCF-7

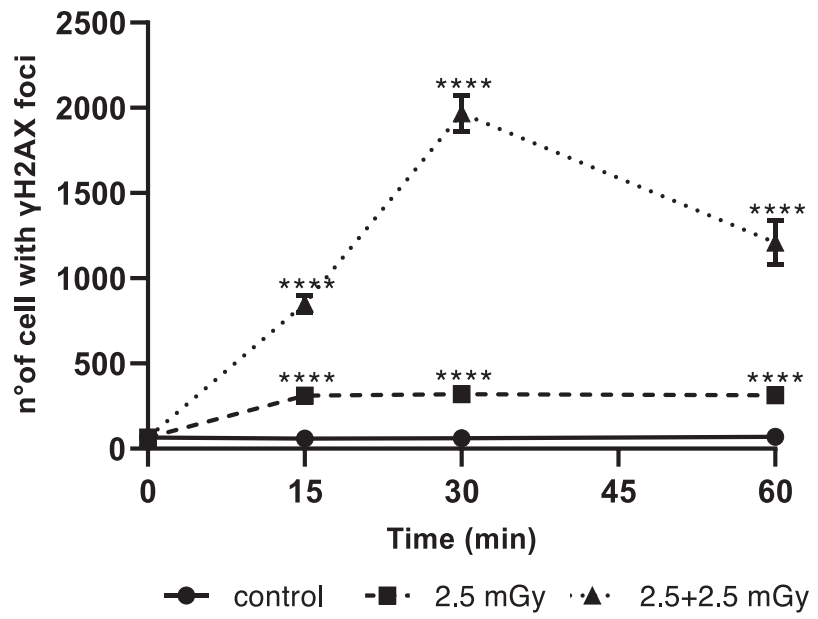

MDA-MB-231

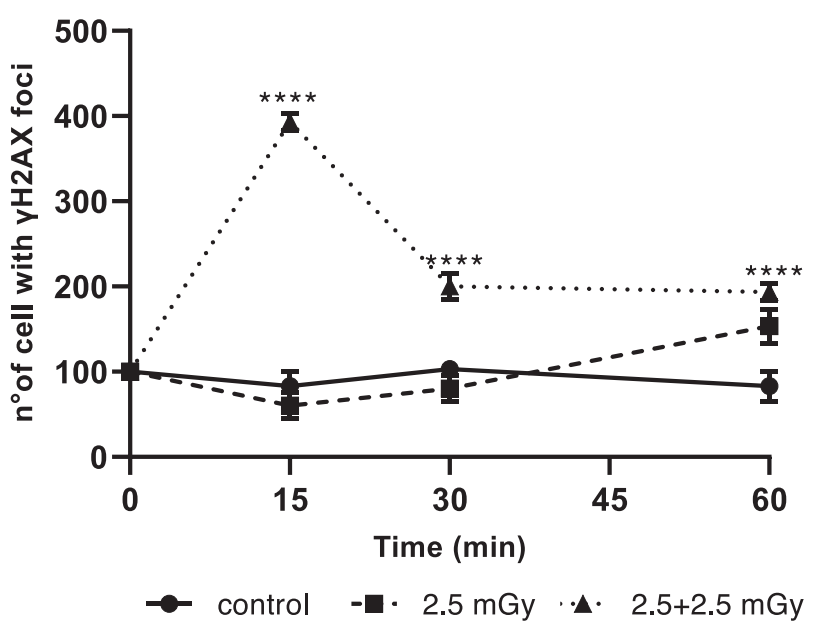

Fig. 3. (continued).

cells. This finding differs from the observations described in another radiodiagnosis study that showed that IR doses below 5 mGy may not induce apoptosis [34].
It is known that cells have several DNA repair mechanisms, and nearly all low dose radio-induced DSBs can be repaired [35,37]. Our results obtained by immunofluorescence analysis showed clear 


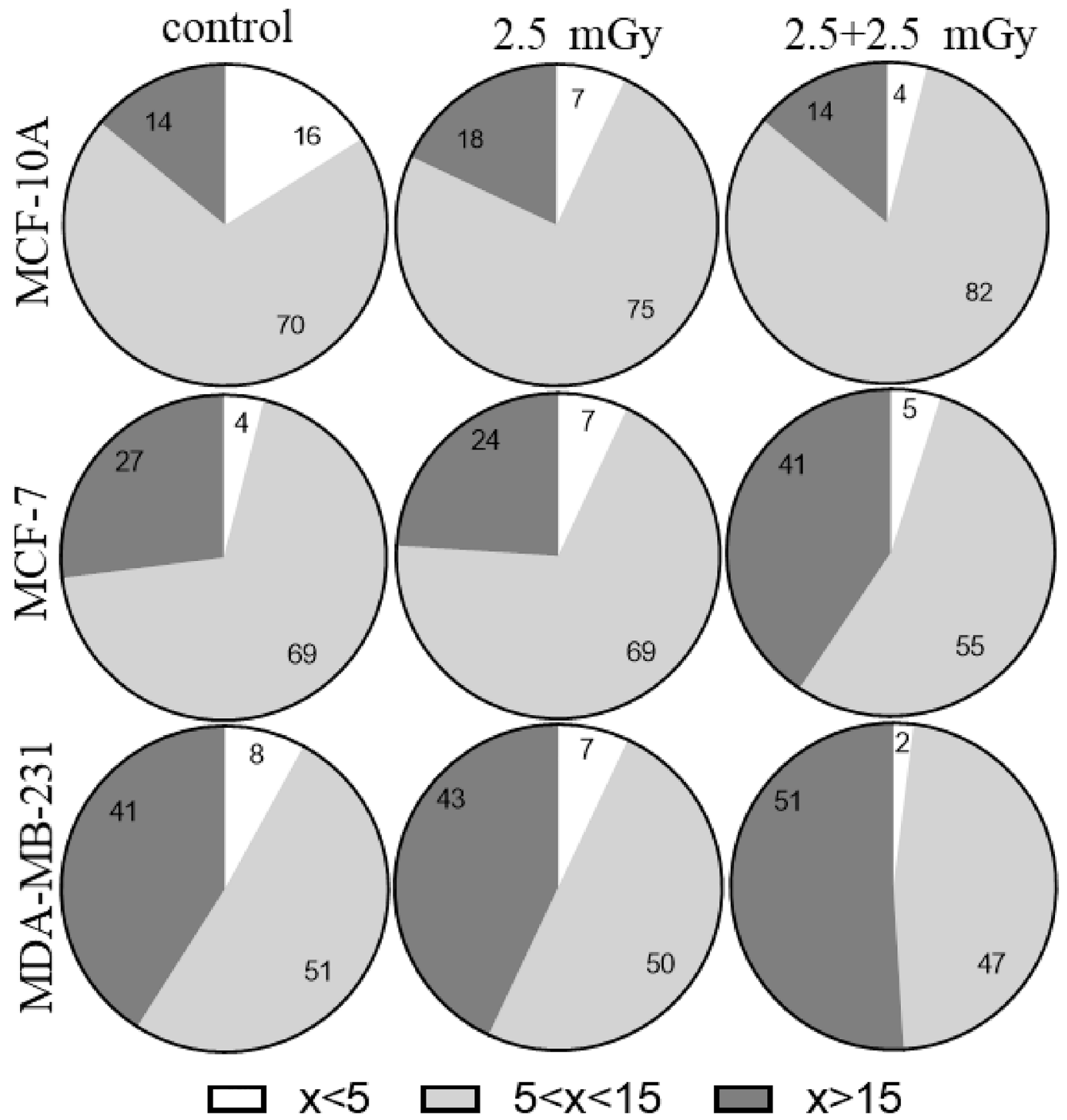

Fig. 3. (continued).

differences between the sizes and amount of the $\gamma \mathrm{H} 2 \mathrm{AX}$ foci, in cells that were exposed to repeated MGD. The cancer cell lines MDA-MB-231 and MCF-7 exhibited the highest number of foci. For the non-tumorigenic cell line MCF-10A, we found a quite stable level of histone activation over time. This could suggest that this cell line has a more efficient mechanism to repair damages to the DNA molecule [38]. Nevertheless, it is not possible to state that all damages have been repaired efficiently, as no analysis of repair mechanisms has been performed so far. On the other hand, the quantification of $\gamma \mathrm{H} 2 \mathrm{AX}$ foci per cell in MCF-10A cells showed that, for both the single and repeated MGD, the largest fraction of cells held 5-15 foci (75\% and 78\% respectively).

Regarding the less invasive tumor cell line, MCF-7, the highest number of $\gamma \mathrm{H} 2 \mathrm{AX}$-positive cells was observed after $30 \mathrm{~min}$, suggesting that the generation of DSBs still occurs after irradiation or that repair mechanisms become less efficient over time [19]. In this cell line, the repeated MGD protocol induced greater activation of $\gamma \mathrm{H} 2 \mathrm{AX}$, implying that it caused greater DNA damage ( $x>15$ foci). The fact that a higher rate of apoptosis was observed with the single-dose MGD irradiation, and that the repeated MGD protocol induced more activation of histone $\mathrm{H} 2 \mathrm{AX}$ could be an indication of inefficiently repaired DSBs. Overall, these observations suggest that MCF-7 cell line seems to be much more sensitive to low dose radiation regimens, such as those delivered during mammographic screening.

For the more aggressive tumor cell line, MDA-MB-231, the maximum activation of $\gamma \mathrm{H} 2 \mathrm{AX}$ occurred only with the repeated MGD and within 15 min after irradiation. So it is not surprising that this damage occurring shortly after exposure to the IR lead to more foci than it did in the other cells (i.e., most cells scored in the $\mathrm{x}>15$ foci group).

When discussing the biological effects at low doses of radiation, the main hypothesis is that each DSB has the same probability of inducing a cellular transformation, regardless of the amount of DSBs present simultaneously in the cell, and that each cell has the same likelihood of developing into cancer regardless of dose [39]. Our findings in the present study suggest that cell responses to mammography typical doses 
do not seem to follow a linear behavior and that non-tumoral breast cells can withstand more ionizing radiation than tumor cells. We found that the tumoral cell line with a less aggressive profile and low metastatic potential (MCF-7) was the most radiosensitive, with the the repeated MGD regimen being the most harmful. For the triple-negative MDA-MB231 cell line, exhibiting a highly invasive and metastatic potential profile, the repeated MGD protocol induced the largest amount of DSBs.

It should be pointed out that we have recently analyzed the expression of some epithelial mesenchymal transition (EMT) biomarkers - in particular, E-cadherin, vimentin and fibronectin - in the same breast cell lines investigated here, while also studying their migratory and invasive behavior (Pereira and colleagues, manuscript submitted). Interestingly, we found that both MGDs irradiation regimens $(2.5 \mathrm{mGy}$ and $2.5+2.5$ $\mathrm{mGy}$ ) promoted significant increases in the expression levels of some of these EMT markers, mainly in MCF-10A and MCF-7 cell lines, besides modulating the migratory and invasive behaviour of all three breast cell lines. However, it seems necessary to further extend our experimental approaches, in order to explore possible correlations between low doseinduced DSBs and other cellular mechanisms seen as crucial for tumor progression, such as EMT and cell migration.

Screening for breast cancer involves controversy and, even today, represents something challenging. Despite these challenges, the current data based on most of the large randomized clinical trials and metaanalysis sets are clear in demonstrating that mammographic screening significantly reduces the risk of mortality from breast cancer $[40,41]$. Our results suggest that tumor grade could represent a relevant factor regarding the susceptibility of breast cancer cells to the biological effects of mammographic doses. Since mammographic screening has a repetitive character and involves a large number of both asymptomatic and symptomatic women, we suggest that more in-depth studies are needed to better understand the effects of low dose exposures on breast cells. Also, it seems essential to define if, and under what conditions, there would be a risky situation in repeated mammographic diagnosis.

\section{Conclusion}

We concluded that the exposure of MCF-10A, MCF-7 and MDA-MB231 breast cell lines to X-rays doses used in mammographic screening did not result in measurable reductions in cell growth and survival, in the experimental conditions of the clonogenic study. However, it induced the formation of $\gamma \mathrm{H} 2 \mathrm{AX}$ foci, in a cell type and time-dependent manner. It was found that there was no linearity in the number of cells exhibiting $\gamma \mathrm{H} 2 \mathrm{AX}$ foci when they were irradiated under the two mammographic conditions, MGD 2.5 and $2.5+2.5$ mGy. Furthermore, repeated MGD, in particular, was able to generate DSB-compatible lesions in the DNA molecule, and these effects were more damaging to less transformed cells, such as the MCF-7 breast tumor cell line. Further investigation would be necessary to elucidate the time interval between H2AX activation and DSB repair. Our observations could have significant clinical implications in the future and may call attention to the importance of expanding studies of the impact of low dose radiation regimens, e.g. compatible with diagnostic practices, by using representative cell models of different stages of the disease, and of various molecular subtypes of breast cancer.

\section{Acknowledgement}

The authors would like to thank Dr. Delson Brás, Ph.D. (in memoriam), from the Nuclear Engineering Department, Federal University of Rio de Janeiro (RJ, Brazil) for his academic guidance.

\section{References}

[1] United Nations Scientific Committee on the Effects of Atomic Radiation (UNSCEAR). Sources and effects of ionizing radiation. Vol II: Effects, annex B. New York: Report to the General Assembly of the United Nations); 2000.
[2] United Nations Scientific Committee on the Effects of Atomic Radiation (UNSCEAR). Biological mechanisms of radiation actions at low doses - A white paper to guide the Scientific Committee's future programme of work. New York: United Nations; 2012.

[3] Yaffe MJ, Mainprize JG. Risk of radiation-induced breast cancer from mammographic screening. Radiology 2011;258(1):98-105.

[4] International Commission on Radiological Protection (ICRP). Recommendations of the International Commission on Radiological Protection. Publication 103. Ann ICRP 37; 2007, pp. 1-332.

[5] Verhaegen F, Reniers B. Microdosimetric analysis of various mammography spectra: Lineal energy distributions and ionization cluster analysis. Radiat Res 2004;162(5):592-9.

[6] Berrington de González A, Reeves G. Mammographic screening before age 50 years in the UK: Comparison of the radiation risks with the mortality benefits. Br J Cancer 2005;93(5):590-6.

[7] Berrington de Gonzalez A, Berg CD, Visvanathan K, Robson M. Estimated risk of radiation-induced breast cancer from mammographic screening for young BRCA mutation carriers. J Natl Cancer Instit 2009;101(3):205-9.

[8] Jansen-van der Weide MC, Greuter MJW, Jansen L, Oosterwijk JC, Pijnappel RM, de Bock GH. Exposure to low-dose radiation and the risk of breast cancer among women with a familial or genetic predisposition: A meta-analysis. Eur Radiol 2010; 20(11):2547-56.

[9] Heyes GJ, Mill AJ, Charles MW. Mammography-oncogenecity at low doses. J Radiol Protoc 2009;29(2A):A123-32.

[10] Pauwels EKJ, Foray N, Bourguignon MH. Breast Cancer Induced by X-Ray Mammography Screening? A Review Based on Recent Understanding of Low-Dose Radiobiology. Med Princ Pract 2016;25(2):101-9.

[11] Hendrick RE, Pisano ED, Averbukh A, Moran C, Berns EA, Yaffe MJ, et al. Comparison of acquisition parameters and breast dose in digital mammography and screen-film mammography in the american college of radiology imaging network digital mammographic imaging screening trial. AJR Am J Roentgenol 2010;194(2):362-9.

[12] Thierry-Chef I, Simon SL, Weinstock RM, Kwon D, Linet MS. Reconstruction of absorbed doses to fibroglandular tissue of the breast of women undergoing mammography (1960 to the present) [published correction appears in Radiat Res. 2012 Mar;177(3):328]. Radiat Res 2012;177(1):92-108.

[13] Körner M, Weber CH, Wirth S, Pfeifer K-J, Reiser MF, Treitl M. Advances in digital radiography: physical principles and system overview. Radiographics 2007;27(3): 675-86.

[14] Granzotto A, Devic C, Viau M, et al. Individual susceptibility to radiosensitivity and to genomic instability; its impact on low doses phenomena. Health Phys 2011;100: 282.

[15] Granzotto A, Joubert A, Viau M, Clément D, Maalouf M, Thomas C, et al. Individual response to ionising radiation: what predictive assay(s) to choose? Compte-rendus de l' A cadé $m$ ie des Sciences. Biologies 2011;334:140-57.

[16] Heyes GJ, Mill AJ. The neoplastic transformation potential of mammography X rays and atomic bomb spectrum radiation. Radiat Res 2004;162(2):120-7.

[17] Joiner MC, Marples B, Lambin P, Short SC, Turesson I. Low-dose hypersensitivity: current status and possible mechanisms. Int J Radiat Oncol Biol Phys 2001;49(2): 379-89.

[18] Jeggo PA, Löbrich M. Contribution of DNA repair and cell cycle checkpoint arrest to the maintenance of genomic stability. DNA Repair (Amst) 2006;5(9-10):1192-8.

[19] Rothkamm K, Lobrich M. Evidence for a lack of DNA double-strand break repair in human cells exposed to very low x-ray doses. Proc Natl Acad Sci USA 2003;100(9): $5057-62$.

[20] Redpath JL, Lu Q, Lao X, Molloi S, Elmore E. Low doses of diagnostic energy X-rays protect against neoplastic transformation in vitro. Int J Radiat Biol 2003;79(4): 235-40.

[21] Ko SJ, Liao X-Y, Molloi S, Elmore E, Redpath JL. Neoplastic transformation in vitro after exposure to low doses of mammographic energy $\mathrm{X}$ rays: quantitative and mechanistic aspects. Radiat Res 2004;162(6):646-54.

[22] Lehnert A, Lessmann E, Pawelke J, Dorr W. RBE of $25 \mathrm{kV}$ X-rays for the survival and induction of micronuclei in the human mammary epithelial cell line MCF-12A. Radiat Environ Biophys 2006;45:253-60.

[23] Chow AY. Cell cycle control by oncogenes and tumor suppressors: driving the transformation of normal cells into cancerous cells. Nat Educat 2010;3(9):7.

[24] Hanahan D, Weinberg R. Hallmarks of cancer: the next generation. Cell 2011;144 (5):646-74.

[25] Depuydt J, Viaene T, Blondeel P, Roche N, Van den Broecke R, Thierens H, et al. DNA double strand breaks induced by low dose mammography X-rays in breast tissue. A pilot study. Oncol Lett 2018. https://doi.org/10.3892/ol10.3892/ ol. 2018.9024.

[26] Comşa Ş, Cîmpean AM, Raica M. The story of MCF-7 breast cancer cell line: 40 years of experience in research. Anticancer Res 2015;35(6):3147-54.

[27] Hernández L, Terradas M, Martín M, Feijoo P, Soler D, Tusell L, et al. Increased mammogram-induced DNA damage in mammary epithelial cells aged in vitro. PLoS One 2013;8(5):e63052.

[28] Colin C, Devic C, Noël A, Rabilloud M, Zabot M-T, Pinet-Isaac S, et al. DNA doublestrand breaks induced by mammographic screening procedures in human mammary epithelial cells. Int J Radiat Biol 2011;87:1103-12.

[29] Mills CE, Thome C, Koff D, Andrews DW, Boreham DR. The relative biological effectiveness of low-dose mammography quality $\mathrm{X}$ rays in the human breast MCF10A cell line. Radiat Res 2015;183(1):42-51.

[30] Collis SJ, Schwaninger JM, Ntambi AJ, Keller TW, Nelson WG, Dillehay LE, et al. Evasion of early cellular response mechanisms following low level radiationinduced DNA damage. J Biol Chem 2004;279(48):49624-32. 
[31] International Atomic Energy Agency, Quality Assurance Programme for Digital Mammography, IAEA Human Health Series No. 17, IAEA, Vienna; 2011.

[32] Franken NAP, Rodermond HM, Stap J, Haveman J, van Bree C. Clonogenic assay of cells in vitro. Nat Protoc 2006;1(5):2315-9.

[33] Aubry J-P, Blaecke A, Lecoanet-Henchoz S, Jeannin P, Herbault N, Caron G, et al. Annexin $\mathrm{V}$ used for measuring apoptosis in the early events of cellular cytotoxicity. Cytometry 1999;37(3):197-204.

[34] Dimova EG, Bryant PE, Chankova SG. Adaptive response: some underlying mechanisms and open questions. Genet Mol Biol 2008·31(2):396-408.

[35] Mavragani IV, Nikitaki Z, Kalospyros SA, Georgakilas AG. Ionizing radiation and complex DNA damage: from prediction to detection challenges and biological significance. Cancers 2019;11(11):1789.

[36] Soule HD, Maloney TM, Wolman SR, Peterson Jr WD, Brenz R, McGrath CM, et al Isolation and characterization of a spontaneously immortalized human breast epithelial cell line, MCF-10. Cancer Res 1990 Sep 15;50(18):6075-86.
[37] Borrego-Soto G, Ortiz-López R, Rojas-Martínez A. Ionizing radiation-induced DNA injury and damage detection in patients with breast câncer. Genet Mol Biol 2015; 38(4):420-32.

[38] Mariotti LG, Pirovano G, Savage KI, Ghita M, Ottolenghi A, Prise KM, et al. Use of the $\gamma$-H2AX assay to investigate DNA repair dynamics following multiple radiation exposures. PLoS One 2013;8(11):e79541.

[39] Tubiana M, Feinendegen LE, Yang C, Kaminski JM. The linear no-threshold relationship is inconsistente with radiation biologic and experimental data. Radiology 2009;251(1):13-22.

[40] Dauer LT, Brooks AL, Hoel DG, Morgan WF, Stram D, Tran P. Review and evaluation of updated research on the health effects associated with low dose ionising radiation. Radia Pro Dosimetry 2010;140(2):103-36.

[41] Lewanski CR, Gullick WJ. Radiotherapy and cellular signalling. Mammography Screening Reduces Rates of Advanced and Fatal. Lancet Oncol 2001;2(6):366-70. 